\title{
Translating Enlightenment: A Review Article of New Books by Stockhorst, Vidal Claramonte, and Tortosa
}

\author{
Mónica Bolufer \\ University of Valencia
}

Follow this and additional works at: https://docs.lib.purdue.edu/clcweb

Part of the Comparative Literature Commons, and the Critical and Cultural Studies Commons

Dedicated to the dissemination of scholarly and professional information, Purdue University Press selects, develops, and distributes quality resources in several key subject areas for which its parent university is famous, including business, technology, health, veterinary medicine, and other selected disciplines in the humanities and sciences.

CLCWeb: Comparative Literature and Culture, the peer-reviewed, full-text, and open-access learned journal in the humanities and social sciences, publishes new scholarship following tenets of the discipline of comparative literature and the field of cultural studies designated as "comparative cultural studies." Publications in the journal are indexed in the Annual Bibliography of English Language and Literature (Chadwyck-Healey), the Arts and Humanities Citation Index (Thomson Reuters ISI), the Humanities Index (Wilson), Humanities International Complete (EBSCO), the International Bibliography of the Modern Language Association of America, and Scopus (Elsevier). The journal is affiliated with the Purdue University Press monograph series of Books in Comparative Cultural Studies. Contact: <clcweb@purdue.edu>

\section{Recommended Citation}

Bolufer, Mónica. "Translating Enlightenment: A Review Article of New Books by Stockhorst, Vidal Claramonte, and Tortosa." CLCWeb: Comparative Literature and Culture 13.1 (2011): <https://doi.org/10.7771/1481-4374.1720>

This text has been double-blind peer reviewed by $2+1$ experts in the field.

The above text, published by Purdue University Press @Purdue University, has been downloaded 698 times as of $11 /$ $07 / 19$.

This document has been made available through Purdue e-Pubs, a service of the Purdue University Libraries. Please contact epubs@purdue.edu for additional information.

This is an Open Access journal. This means that it uses a funding model that does not charge readers or their institutions for access. Readers may freely read, download, copy, distribute, print, search, or link to the full texts of articles. This journal is covered under the CC BY-NC-ND license. 


\section{PURDUE}

UNIVERSITY PRESS <http://www.thepress.purdue.edu>

\section{CLCWeb: Comparative Literature and Culture}

ISSN 1481-4374 <http://docs.lib.purdue.edu/clcweb> Purdue University Press (CPurdue University

CLCWeb: Comparative Literature and Culture, the peer-reviewed, full-text, and open-access learned journal in the humanities and social sciences, publishes new scholarship following tenets of the discipline of comparative literature and the field of cultural studies designated as "comparative cultural studies." In addition to the publication of articles, the journal publishes review articles of scholarly books and publishes research material in its Library Series. Publications in the journal are indexed in the Annual Bibliography of English Language and Literature (Chadwyck-Healey), the Arts and Humanities Citation Index (Thomson Reuters ISI), the Humanities Index (Wilson), Humanities International Complete (EBSCO), the International Bibliography of the Modern Language Association of America, and Scopus (Elsevier). The journal is affiliated with the Purdue University Press monograph series of Books in Comparative Cultural Studies. Contact: <clcweb@purdue.edu>

Volume 13 Issue 1 (March 2011) Book Review Article Mónica Bolufer, "Translating Enlightenment:

A Review Article of New Books by Stockhorst, Vidal Claramonte, and Tortosa" $<$ http://docs.lib.purdue.edu/clcweb/vol13/iss1/15>

Contents of CLCWeb: Comparative Literature and Culture 13.1 (2011)

<http://docs.lib.purdue.edu/clcweb/vol13/iss1/> 
Mónica Bolufer,

"Translating Enlightenment:

A Review Article of New Books by Stockhorst, Vidal Claramonte and Tortosa"

page 2 of 6

CLCWeb: Comparative Literature and Culture 13.1 (2011): <http://docs.lib.purdue.edu/clcweb/vol13/iss1/15>

\section{Mónica BOLUFER}

\section{Translating Enlightenment:}

\section{A Review Article of New Work by Stockhorst, Vidal Claramonte, and Tortosa}

Translation studies attained considerable development in the past decades and can be considered an extraordinary dynamic field. A boom in publications and the proliferation of conferences and collective interdisciplinary projects has made translation a rising area of research. Not only translating between different languages is more and more a practical need in the modern world of global commerce, crosscultural fluxes, and international institutions. Also, theories of translation have become increasingly complex and sophisticated as they have assimilated the impact of theories of language (from reception aesthetics to deconstruction, feminist criticism and postcolonial studies), which have definitely shattered a notion of language as the transparent vehicle of ideas. If language shapes, rather than just reflects, reality, then translation can no longer be deemed a neutral, merely linguistic exercise, but an act which produces endlessly new meanings.

Translation is often interdisciplinary concerning the disciplines of linguistics, modern (and ancient) languages, literary and culture study, sociology, history, and computer science. In my case, from the point of view of a historian, the practices of translation in the past lay at the intersection of literary and historical studies. They are a fruitful research object where the complementary, yet distinctive, approaches of intellectual and cultural history can come together, drawn by the interest to analyze how discourses take shape and are reframed and transformed in different contexts: through time, across geographical boundaries, through individual and collective appropriation. An old insight of cultural history, deeply influenced by reception theories from the 1960s, has been the attention to how reception (through reading, watching, listening) is never a passive act, nor homogeneous nor can be fully predicted (see Burke; Chartier, "The World"). Ideas and texts do not flow in the void. They can only exist and be apprehended (by their contemporaries and [later] by scholars) through their material forms: as words which are written, voiced, copied, published, read, censored, hidden in clandestinity; of course, also translated. Therefore, the social and cultural history of translation, far from concerning itself with the limited question of how accurate or "loyal" the translated work is in relation to the original, takes interest in researching which works and authors were translated in a particular time and place, in finding out who their translators were, the presses which published them, and the eventual patrons who blessed them with their financial help, in what sense were the texts transformed to adapt them to new circumstances, what kind of reception they received, what uses they were put to by different kinds of readers, and how they were envisaged and eventually promoted, tolerated, or prohibited by civil and religious authorities; in which ways they were gendered; what do they tell us about power struggles within the republic of letters. These are a few among other relevant questions. Old and new concerns can be illuminated by the insights of translation theory but also, more generally, history and translation studies should fertilize each other.

The three books under review here - Stefanie Stockhorst, ed. Cultural Transfer Through Translation: The Circulation of Enlightened Thought in Europe by Means of Translation, María Carmen África Vidal Claramonte, En los límites de la traducción, and Virgilio Tortosa, ed. Re-escrituras de lo global. Traducción e interculturalidad - represent a panorama of recent developments in the field. They can also be seen as tracing a scale which embraces from theoretical discussions about the very concept of translation to practical reflection of the intellectual and ethical challenges faced by translators today in specific genres/languages/contexts to empirical research on how translation shaped/was shaped by a particular culture, that of the eighteenth-century European Enlightenment. As Virgilio Tortosa, editor of Re-escrituras de lo global. Traducción e interculturalidad points out, in the field of translation - and certainly also in that of history and more generally in any intellectual endeavor - theory and practice cannot be understood without each other. And the volumes bear out this principle: authors in these three volumes include translation scholars, professional translators, literary critics, and historians whose complementary approaches make valuable contributions to the field. 
Mónica Bolufer,

"Translating Enlightenment:

A Review Article of New Books by Stockhorst, Vidal Claramonte and Tortosa"

page 3 of 6

CLCWeb: Comparative Literature and Culture 13.1 (2011): <http://docs.lib.purdue.edu/clcweb/vol13/iss1/15>

The first of the two works, written and edited, respectively, by two scholars who had already produced other publications on translation (Vidal Claramonte, El futuro) and other subjects connected with the social uses of modern literature, concern themselves mainly, in some way or the other, with the effect of postmodern thought and contemporary social developments contemporary theories and practices of translation. An underlying theme in both of them is the (relatively) new status of translation and of translators in modern thought and practice. The traditional ideal of the translator was that of an "invisible hand" behind a text which would replicate as accurately as possible the original, presenting itself as replicating the latter. His/her necessary expertise would consist in disappearing from the text, creating for readers the illusion of being in front of another original, resembling the perfect housewife (the "angel of the house" in eighteenth- and nineteenth-century literature), whose carefully trained expertise in domestic matters should never show but would result in things running smoothly producing the illusion of a "natural," almost providential, order and domestic bliss. As a result of new theories of language and of self-conscious reflections by new generations of translators, the sharp divisions, once taken for granted, between original and translated, are no longer accepted. Clean-cut dichotomies between creative and derivative work have been substituted by the idea of a continuum of readings and appropriations, of which translations are but one case among others (new editions, imitations, adaptations). Therefore, the translator is seen not in stark opposition to the author/creator, but as a particular (privileged?) kind of reader, whose intervention on the text is always interpretive and invests it with new inflections.

In this respect, what means translating in the modern world and which might be some of the (best) possible practices in the new intellectual, social, and political circumstances are some of the central themes that the first two of these books handle. At the heart of both lies a timely warning: the postmodern consciousness of the multiplicity of readings, the impossibility of establishing, once and for all, definitive meanings (also definitive translated versions) should not lead to consider that all translations are equally valuable, that the (endless) search for accuracy is pointless. Translation in the modern world should find its way "at its very limits," as suggests the title of Vidal Claramonte's book, just as history, "on the edge of the cliff," as Roger Chartier (On the Edge) put it, should not be discouraged, but rather stimulated, by the self-conscious notion of its discursive, rather than transparent scientific nature. The two books deal with their subject in different ways. Vidal Claramonte's En los límites de la traducción is a brief but dense text, introduced by an illuminating preface by Rosemary Arrojo. The book is full of literary (and also artistic) references, taken from the works of writers particularly conscious of the ambiguities and the power of language. It is also, it must be noted as one of its virtues, exquisitely written, with clarity and, at the same time, capacity for suggestion not so easily found in the field of language theory, often arid for the non-specialists. Although strongly rooted in an excellent knowledge of translation theories, it has the ability of connecting theoretical discussions to the practical challenges and dilemmas which translators must face when doing their work. How to translate in an age when uncertainty about the very possibility of "translating" in the traditional sense (that is, of converting accurately from one language to another one, with the least possible change understood as "loss") prevails? Will translators be paralyzed by the acute consciousness of the fact that translation is never an innocent, neutral action, but always implies new meanings in new contexts?

Vidal Claramonte illustrates this situation by pointing at examples of translations of experimental literature, where all these dilemmas are brought to the forefront. In some cases, the translator's voice is made deliberately audible, and the reader is shown a display of possible options, in order to remind him/her of the multiple, never innocent choices, translators are constantly obliged to make, to involve him/her, to some extent, in the very process of taking these decisions, and in this way to raise discussions about the problematic nature of translations. Again, this makes one think of some of the insights of historians like Carlo Ginzburg, who chooses to show not only the results of their research, which, by implication, would then seem conclusive, but the very process of displaying one's sources, acknowledging their limitations, making hypothesis, weighting possibilities, taking options, and discarding others, cunningly picking up narrative strategies. Both to attract readers by means of carefully framed narratives and to raise epistemological questions about the tentative nature of historical knowledge 
Mónica Bolufer,

"Translating Enlightenment:

A Review Article of New Books by Stockhorst, Vidal Claramonte and Tortosa"

page 4 of 6

CLCWeb: Comparative Literature and Culture 13.1 (2011): <http://docs.lib.purdue.edu/clcweb/vol13/iss1/15>

and its rhetorical dimension, historians nowadays tend to show their cards, rather than pretend their research to be completely neutral. Like historians, translators have not only an intellectual, but an ethical responsibility: this is illustrated by Vidal Claramonte with examples of how an inaccurate translation (due to a lack of expertise, both linguistic and cultural) can distort communication, and therefore influence the final outcome of legal procedures. These cases are illuminating because they show at its most how the search for precision and accuracy should not be dismissed as irrelevant or unattainable.

If Vidal Claramonte's book can be taken as a very pertinent reflection on postmodernism's impact on modern practices of translation, its insights and its shortcomings, Tortosa's multi-authored $R e$ escrituras de lo global. Traducción e interculturalidad situate these contemporary concerns in a longer tradition, showing how translation as a practice has been controversial throughout history, from classical rhetoric to modern linguistics. As the editorial introduction makes clear, its general context is that of the new protagonism of translation in the modern world of global society, global communication, and the shattering of the long-established dichotomies between centres and peripheries. If translation, as the introduction and some of the essays in the book very appropriately argue, is often, whether deliberately or not, an exercise of power, it is also an opportunity to give voice to the usually voiceless (minority languages, cultures, and social groups). The volume is organized in four clearly structured parts. The first one deals with issues of translation theory: questions of language, power, reception, the role of the reader and of the translator (articles are by García Yebra, Aullón de Haro, Chico Rico, Tortosa, Vidal Claramonte, and Tötösy de Zepetnek). The articles in the second part cover translation to and from languages historically close to Spanish, including English, French, Italian, Portuguese, Catalan, German, and Arabic: the rises and falls in translations, linked to cultural and political circumstances, the danger of "false friends" bewteen somewhat similar languages, the options for translating peculiar varieties or registers which denote social or geographical origins (articles are by García Tortosa, Lafarga, Benavent, Cuadrado, Martines Peres, and Albaladejo Martínez). The third part develops the idea of translation as a metaphor for cultural transfer, in particular from one code to another literary, musical, architectural, cinematographical, among others (articles are by Lozano, Bou, Parra Bañon, Pérez, and Zumalde Arregi). And the fourth part is with articles written by professional translators who reflect on their experience in specific genres: narrative, drama, and poetry (articles are by Sáenz, Matteini, and Siles). Many of the authors in the volume are either professional translators or have had some experience as such. This probably accounts for their particular sensibility to the social, professional and ethical dimensions of this activity. On one hand, they seem to aim at arising consciousness among translators of the many implications (cultural, moral, political) of their work, so that they handle with care their often difficult choices. On the other hand, they express concern for the fact that such a complex activity as translations, which requires long experience and wide linguistic and intellectual skills, is not highly regarded (neither highly paid) by the editorial bussiness.

The third work under review here, Stefanie Stockhorst, ed. Cultural Transfer Through Translation:

The Circulation of Enlightened Thought in Europe by Means of Translation focuses on the specific meanings of translation in Enlightenment thought and cultural practices. Its introduction offers a well documented presentation of translation in the historically-specific cultural landscape of eighteenthcentury Europe. Stockhorst argues for adopting the notion of cultural transfer, first formulated in the mid-1980s by Michel Espagne and Michael Werner in the context of a research project on FrancoGerman cultural relations from 1750 to 1914 , as a more useful concept than that, too one-sided, of "influence" in order to deal with cultural movements and transformations. Her proposal can be seen as a further development of the notion of "reception," the way it was formulated and used in Fania OzSalberger's (herself a contributor to this volume) pioneering research into the German reception of the Scottish Enlightenment: "the creative process whereby one culture is enrichened and inspired by another, even as it transforms some of the ideas it receives" (Oz-Salzberger, Translating 3). Translation is, then, one of the ways in which cultural transfer operates: a symptom, and at the same time a consequence of, intellectual interests and social demand for specific genres or subjects, be it sentimental literature (Krake and Eyck), essay-periodicals (Stone), travel narratives (Martin) or experimental philosophy (Zuidervaart). The introduction is a doorway to a selection of articles which offer carefully se- 
Mónica Bolufer,

"Translating Enlightenment:

A Review Article of New Books by Stockhorst, Vidal Claramonte and Tortosa"

page 5 of 6

CLCWeb: Comparative Literature and Culture 13.1 (2011): <http://docs.lib.purdue.edu/clcweb/vol13/iss1/15>

lected and painstakingly researched case-studies focusing on varied territories and literatures: from French and English to Spanish, Italian, Swedish, and Russian. For the non-expert reader, it comes as an interesting surprise that the flux of translations in the eighteenth century not only was about the irradiation of French books and ideas, but also composed other, more complex constellations which did not exclude "minor" languages (like Dutch, Italian, Swedish) and incorporated different, sometimes overlapping, areas of circulation (i.e. the Scandinavian countries). The essays included in the volume sum up, and at the same time further advance, more than a decade of previous studies of translation during the eighteenth century. Taken altogether, they reinforce a picture in which not all the roads lead to Paris, but also go to and from London, Napoli, Amsterdam (here the wide success of Rhijnvis Feith's 1783 Julia is illuminating), Madrid, Göttingen, etc. The cultural or intellectual historian will easily connect this idea with the developments in Enlightenment studies during the past decades, among them the expansion of the map of the Enlightenment, once limited to the French philosophes and German thinkers, to encompass the whole of Europe (and some of its colonial territories), and the growing interest in the interplay (and conflict) between its cosmopolitan and national dimensions. To cite again Oz-Salzberger phrasing, translation is one of the evidences that the Enlightenment was "an intercultural rather than a flatly cosmopolitan movement" (Oz-Salzberger, Translating 2). The articles in this volume demonstrate how "national" literatures can no longer be written (even without raising the question of the problematic relation between "languages" and "nations") if one does not take into consideration the role played in a certain literature by translated works, not considered as mere imitations, but as genuine acts of reception and creation, and therefore as valuable cultural indicators. This is an assertion which has also been made in recent and influential studies of particular genres, above all the eighteenth-century novel, like those of Jenny Mander or Ana Rueda. They also very appropriately remind us that translations, although they can be framed in general, collective contexts, were the work of particular individuals, about whom more biographical, "microhistorical" research still has to be done.

Other questions relevant for eighteenth-century history are also raised in the book such as the origins of a modern notion of translation, conscious of cultural diversity (Lifschitz), the relation between rhetoric and art theory and their respective notions of "imitation" (Oberstebrink), the role played by patrons in promoting not only writing and publishing but also translating, or the making of the public sphere, among others. However, precisely because of the very richness of the intellectual and social history of translation this volume offers, it is intriguing to note it hardly deals with its gendered practices. Many studies have thoroughly demonstrated how translation was in the eighteenth century (and beyond) an activity frequently displayed, all over Europe, by women, who used it to legitimize their access to the republic of letters, and thus benefited from (and also contributed to) blurring the distinctions between translation and creation (Fidecaro, Partzch, Van Dijk, Cossy). For this reason, translation figures prominently in the most up-to-date research projects on women's writing (see, for instance, the COST Action ISO901 Women Writers in History. Toward a New Understanding of Europe's Literary Culture: <www.womenwriters. nl>). Incorporating this gender perspective would have further enhanced the interest of the remarkable collective work put together by Stockhorst.

In conclusion, these books should be welcome not only by translation experts, but also by scholars in the neighboring fields of history, literary study, sociology, and cultural studies as stimulating contributions to the study of cultural transfers and fluxes in the past, as well as the present.

\section{Works Cited}

Burke, Peter. What is Cultural History. Cambridge: Polity P, 2004.

Chartier, Roger. "The World as Representation." Histories: French Constructions of the Past. Ed. Jacques Revel and Lynn Hunt. New York: New P, 1995. 544-58.

Chartier, Roger. On the Edge of the Cliff: History, Language, and Practices. Baltimore: The Johns Hopkins UP, 1997.

Fidecaro, Agnese, Henriette Partzsch, Suzan van Dijk, and Valérie Cossy, eds. Femmes écrivains à la croisée des langues / Women Writers at the Crossroads of Languages, 1700-2000. Genève: Métis P, 2009.

Mander, Jenny, ed. Remapping the Rise of the European Novel. Oxford: Voltaire Foundation, 2007. 
Mónica Bolufer,

"Translating Enlightenment:

A Review Article of New Books by Stockhorst, Vidal Claramonte and Tortosa"

page 6 of 6

CLCWeb: Comparative Literature and Culture 13.1 (2011): <http://docs.lib.purdue.edu/clcweb/vol13/iss1/15>

Stockhorst, Stefanie, ed. Cultural Transfer Through Translation: The Circulation of Enlightened Thought in Europe by Means of Translation. Amsterdam: Rodopi, 2010.

Oz-Salzberger, Fania. Translating the Enlightenment. Scottish Civic Discourse in Eighteenth-Century Germany. Oxford: Clarendon, 1995.

Oz-Salzberger, Fania. "The Enlightenment in Translation: National and Regional Aspects." European Review of History 13.3 (2006): 385-409.

Rueda, Ana. Cartas sin lacrar. La novela epistolar y la España ilustrada, 1789-1840. Frankfurt: Iberoamericana/Vervuent, 2001.

Tortosa, Virgilio, ed. Re-escrituras de lo global. Traducción e interculturalidad. Madrid: Biblioteca Nueva, 2008.

Vidal Claramonte, María Carmen África. El futuro de la traducción: últimas teorías, nuevas aplicaciones. Valencia: Institució Alfons el Magnànim, 1998.

Vidal Claramonte, María Carmen África. En los límites de la traducción. Granada: Comares, 2005.

Reviewer's Profile: Mónica Bolufer teaches early modern history at the University of Valencia. Her interests in research include eighteenth-century Spanish and European cultural history, women's writing and translation, travel narratives and the construction of European identity, concepts of politeness and ideas of progress, the history of the family, and the dissemination of medical knowledge. In addition to numerous articles, her book publications include Mujeres e Ilustración (1998), Amor, matrimonio y familia (1998), a critical edition of Antonio Ponz, Viaje fuera de España 1785 (2007), and La vida y la escritura en el siglo XVIII. Inés Joyes: "Apología de las mujeres" (2008). Email: <monica.bolufer@uv.es> 